\title{
STRATEGI PENGELOLAAN PAJAK DAERAH DALAM MENINGKATKAN PENDAPATAN ASLI DAERAH (PAD) KOTA BANJARMASIN
}

\author{
Oleh: \\ Eny Fahrati, Dewi Rahayu, Ika Chandriyanti, \\ Ahmad Yunani, Anshar Nur, Na'imatul Aufa \\ Dosen Fakultas Ekonomi dan Bisnis Universitas Lambung Mangkurat
}

\begin{abstract}
This study aims to determine the effectiveness, efficiency and strategy of local tax management to increase the local receipt (PAD). The analysis technique used is descriptive analysis and SWOT analysis. The result of the research shows that the 20112015 average of effectiveness ratio of Banjarmasin City Local Tax is included in very effective category, so also efficiency ratio is in very efficient category. In detail the Local Taxes by type belonging to very effective categoriesinclude Hotel Tax, Restaurant Tax, Street Lighting Tax, Parking Tax, and Rural and Urban Land and Building Tax (PBB-PP). Fairly effective categories include Entertainment Tax and Advertising Tax, less effective category is a BPHTB tax, while the Swallow's Nest Tax is an ineffective category. Overall efficiency averages fall into the most efficient category, except the Tax on Land and Building Acquisition (BPHTB) and Rural andUrban Land and Building Tax (PBB-PP) which fall into the efficient category. Strategies to increase Local Receipt (PAD) are 1) to socialize and publicize services and public awareness of the importance of Local Taxes 2) Increase the use of better information technology so as to increase the capability in validation of tax potentials and levies more valid, 3) Simplify the bureaucratic stage and increase online services in terms of tax payments so as to attract public interest to pay taxes.
\end{abstract}

Keyword: Local Receipt, Local Tax, Effectiveness Ratio, Efficiency Ratio

Abstrak: Penelitian ini bertujuan untuk mengetahui efektivitas, efisiensi dan strategi pengelolaan Pajak Daerah dalam meningkatkan Pendapatan Asli Daerah (PAD). Teknik analisis yang digunakan adalah analisis deskriptifdan analisis SWOT. Hasil penelitian menunjukkan bahwa rata-rata tahun 2011-2015 rasio efektivitas Pajak Daerah Kota Banjarmasin termasuk dalam kategori sangat efektif, begitu pula dengan rasio efisiensi berada dalam kategori sangat efisien. Secara rinci Pajak Daerah menurut jenisnyayang termasuk kedalam kategori sangat efektif meliputi Pajak Hotel,Pajak Restoran, Pajak Penerangan Jalan Umum, Pajak Parkir, dan Pajak PPB Perdesaan dan perkotaan, kategori cukup efektif meliputi Pajak Hiburan dan Pajak Reklame, kategori kurang efektif adalah Pajak BPHTB, sedangkan Pajak Sarang Burung Walet termasuk kategori tidak efektif.Secara keseluruhan rata-rata efisiensi termasuk kedalam kategori sangat efisien, kecuali Pajak Bea Perolehan Hak Atas Tanah dan Bangunan dan Pajak PPB Perdesaan dan perkotaan yang termasuk ke dalam kategori Efisien.Strategi untuk meningkatkan Pendapatan Asli Daerah (PAD) adalah (1) melakukan sosialisasi dan publikasi tentang pelayanan dan kesadaran masyarakat akan pentingnya pajak daerah (2) Meningkatkan penggunaan teknologi informasi yang lebih baik sehingga meningkatkan kemampuan dalam pendataan potensi pajak dan retribusi yang lebih valid, (3) Menyederhanakan tahapan birokrasi serta peningkatan layanan online dalam hal pembayaran pajak sehingga dapat menarik minat masyarakat untuk membayar pajak. Kata Kunci: Pendapatan Asli Daerah, Pajak Daerah, Rasio Efektivitas, Rasio 


\section{Pendahuluan}

Proses Pembangunan Nasional harus melibatkan seluruh komponen, baik pemerintah pusat, pemerintah provinsi, kabupaten dan kota, bahkan sampai ketingkat pemerintahan desa dan terlebih lagi adanya keikutsertaan masyarakat dalam mendukung tercapainya sasaran pembangunan yang diinginkan.

Menurut Undang Undang Nomor 23 Tahun 2014 tentang Pemerintahan Daerah, bahwa Pemerintah Daerah menyelenggarakan urusan pemerintahan yang menjadi kewenangannya kecuali urusan pemerintahan yang oleh undangundang ini ditentukan menjadi urusan pemerintah dalam menyelenggarakan urusan pemerintahan yang menjadi kewenangan daerah sebagaimana dimaksud pemerintah daerah menjalankan otonomi seluas-luasnya untuk mengatur dan mengurus sendiri urusan pemerintahan berdasarkan asas otonomi dan tugas pembantuan.

Otonomi daerah akan berdampak pada semakin besarnya wewenang dan tanggung jawab yang diberikan kepada daerah dalam mengelola pembangunan dan keuangan di daerahnya masing-masing. Disamping hal ini akan berdampak positif, perlu juga diantisipasi kemungkinan timbulnya dampak negatif. Salah satu bentuk dampak negatif desentralisasi dalam pengelolaan pembangunan dan keuangan daerah adalah kemungkinan bergesernya korupsi, kolusi, dan nepotisme (KKN) dari pusat ke daerah.

Peraturan Pemerintah tentang Pengelolaan Keuangan Daerah sebagai terjemahan dari pasal UU Nomor 32 dan Nomor 33 Tahun 2004 nampaknya telah berusaha menjembatani tuntutan masyarakat dan daerah dalam pengelolaan keuangan daerah yang baik dan berorientasi pada kepentingan publik. Kedua UndangUndang tersebut menyadari bahwa, pada dasarnya Otonomi Daerah maupun desentralisasi manajemen ditujukan untuk memberikan keleluasaan kepada Pemerintah Daerah untuk melaksanakan fungsi pelayanan kepada masyarakat dalam rangka meningkatkan kesejahteraan.

Hakekat semangat otonomi ini harus tercermin dalam pengelolaan Keuangan Daerah mulai dari proses perencanaan, pelaksanaan, pengawasan, pengendalian dan evaluasi. Dengan kata lain, daerah harus mempunyai kewenangan untuk merencanakan, menggunakan dan mempertanggungjawabkan pengelolaan seluruh sumber penerimaan daerah kepada masyarakat melalui Dewan Perwakilan Rakyat Daerah (DPRD) tanpa adanya intervensi Pemerintah Pusat seperti dimasa lalu.

Untuk mengatur dan mengurusi rumah tangganya, suatu daerah memerlukan dana. Dengan berlakunya Undang-Undang Nomor 32 Tahun 2004 dan UndangUndang Nomor 33 Tahun 2004 yang kemudian mengalami perubahan menjadi Undang-Undang No. 23 Tahun 2014, Pemerintah Daerah dapat membiayai daerah dari penerimaan daerahnya sendiri. Pentingnya Pendapatan Asli Daerah (PAD) dalam menyelenggarakan otonomi daerah sangat disadari oleh pemerintah daerah sesuai dengan kebutuhan daerah (aspirasi daerah) serta berguna untuk memperkecil ketergantungan dari dana pemerintah pusat. Menurut pendapat dari Widjaya (2002), bahwa Pendapatan Asli Daerah merupakan salah satu modal dasar pemerintah daerah dalam rangka mendapatkan dana pembangunan dan memenuhi belanja daerah guna memperkecil ketergantungan dalam mendapatkan dana pemerintah tingkat atas (subsidi).

Jadi PAD tidak dapat sepenuhnya membiayai APBD, proporsi PAD terhadap total penerimaan tetap merupakan indikasi derajat kemampuan kemandirian keuangan suatu pemerintah daerah. Semakin besar jumlah PAD yang diterima oleh daerah, maka semakin mandiri (tidak tergantung) keuangan daerahnya dan begitu pula sebaliknya.

Seperti daerah-daerah lainnya di Indonesia, Pemerintah Daerah Kota 
Banjarmasinberharap melalui otonomi PAD dapat meningkat.Meskipun kenyataannya sumber-sumber PAD tersebut belum mampu menutupi seluruh pengeluaran APBD,akan tetapi sumber PAD tetap menjadi indikator pendorong peningkatan kemajuan dan kemandirian keuangan daerah Kota Banjarmasin. Dalam upaya meningkatkan PAD tersebut, perlu usaha-usaha untuk menggali potensi PAD baik yang bersumber dari pajak daerah maupun retribusi daerah.

Penetapan target memerlukan kajian mendalam agar penetapan target dan realisasi yang lebih realistis dan sesuai dengan potensi yang dimiliki. Hal ini dilatarbelakangi oleh paradigma tertentu dimana apabila target PAD tercapai atau melebihi target, maka para pemungut (dinas terkait) merasa puas, karena kinerjanya dianggap bagus. Padahal yang terjadi dibanyak instansi (dinas terkait) penetapan target PAD yang dibebankan pada instansinya jauh berada di bawah potensi yang dimilikinya Disisi lain, perlu juga dilihat lebih mendalam mengapa terjadi penurunan target dan apa kendala yang dihadapi dalam realisasi pendapatan asli daerah.

Penelitian Kajian Potensi PAD dalam Rangka Peningkatan Pendapatan Daerah (Saleh, dkk., 2005) di Kabupaten Banjar, yang meneliti tentang pajak galian C, retribusi parkir, retribusi terminal dan retribusi pasar, menunjukkan hasil bahwa, Pajak galian $\mathrm{C}$ penetapan targetnya hanya $76,25 \%$ dari potensi, retribusi parkir $13,79 \%$ dari potensi, retribusi terminal hanya $11,83 \%$ dari potensi, dan retribusi pasar hanya $77,94 \%$ dari potensi. Padahal setiap tahun target yang ditetapkan sudah terlampaui. Bila dilihat dari kinerja Dinas terkait semuanya baik, karena masingmasing Dinas tersebut telah memenuhi target yang telah ditetapkan. Akan tetapi yang terjadi sebenarnya penetapan target masih jauh di bawah potensi yang dimiliki,sehingga wajar kalau target yang direncanakan selalu tercapai.
Pajak Daerah merupakan sumber terbesar Pendapatan Asli Daerah (PAD), sehingga efisiensi dan efektivitas dalam hal penggalian potensi dan pemungutan Pajak Daerah menjadi hal yang sangat penting dalam upaya meningkatkan Pendapatan Asli Daerah. Oleh karena itu perlu dilakukan penelitian mengenai tingkat efektivitas dan efisiensi Pajak Daerah, kendala yang dihadapi dalam pemungutan pajak daerah serta strategi apa yang perlu dilakukan dalam pengelolaan pajak daerah dalam rangka meningkatkan Pendapatan Asli Daerah (PAD).

\section{Tinjauan Pustaka \\ Pendapatan Asli Daerah}

Berdasarkan Undang-Undang Nomor 23 Tahun 2014 tentang Pemerintah Daerah pasal 285, Pendapatan Asli Daerah meliputi pajak daerah, retribusi daerah, hasil pengelolaan kekayaan Daerah yang dipisahkan, dan lain-lain Pendapatan Asli Daerah yang sah.

Selanjutnya menurut UU No. 23 Tahun 2014 Pasal 286, ayat (1) Pajak daerah dan retribusi daerah ditetapkan denganundang-undang yang pelaksanaan di Daerah diatur lebihlanjut dengan Perda dan ayat (2) Pemerintah Daerah dilarang melakukan pungutan ataudengan sebutan lain di luar yang diatur dalam undangundang.

Oleh karena itu, pemerintah daerah mempunyai kewenangan penuh untuk menggali potensi daerah yang dapat meningkatkan Pendapatan Asli Daerah (PAD), termasuk membuat peraturanperaturan daerah yang bertujuan mengoptimalkan pendapatan bagi daerah. Peraturan-peraturan tersebut hendaknya mengacu pada kapasitas lokal dan penciptaan iklim yang kondusif terhadap pertumbuhan ekonomi daerah yang tinggi.

Berdasarkan pengertian Pendapatan Asli Daerah (PAD) seperti yang tercantum dalam UU No. 23 Tahun 2014 tersebut, maka sumber-sumber Pendapatan Asli Daerah (PAD) adalah: 1) Pajak Daerah, 2) 
Retribusi Daerah, 3) Hasil Pengelolaan kekayaan daerah yang dipisahkan, dan 4) Lain-lain Pendapatan Asli Daerah yang sah.

\section{Pajak Daerah}

Menurut Undang-Undang RI Nomor 28 Tahun 2009 yang merupakan perubahan Undang-Undang Nomor 34 Tahun 2000tentang Pajak Daerah dan Retribusi Daerah, "Pajak Daerah yang selanjutnya disebut Pajak, adalahkontribusi wajib kepada Daerah yang terutang oleh orangpribadi atau badan yang bersifat memaksa berdasarkanUndang-Undang, dengan tidak mendapatkan imbalansecara langsung dan digunakan untuk keperluan Daerahbagi sebesar-besarnya kemakmuran rakyat".

Jadi pajak daerah ini, merupakan pajak yang kewenangan pemungutannya dilakukan oleh Pemerintah Daerah dan besarannya diatur dan sesuai dengan Peraturan Daerah.

Dari segi kewenangan pemungutan pajak atas objek Pajak Daerah, Pajak Daerah dibagi menjadi 2 (dua) yakni :

1) Pajak Daerah yang dipungut oleh Pemerintah Provinsi

2) Pajak Daerah yang dipungut oleh Pemerintah Kabupaten/kota

Selain perbedaan kewenangan pemungutan, perbedaan antara Pajak Daerah Propinsi dengan Pajak Daerah Kabupaten/Kota adalah :

1) Objek pajak Kabupaten/Kota lebih luas dibandingkan dengan objek pajak Provinsi;

2) Objek Pajak Kabupaten/Kota masih dapat diperluas berdasarkan Peraturan Pemerintah sepanjang tidak bertentangan dengan ketentuan yang ada. Pajak Daerah tingkat Propinsi, bila akan diperluas objeknya harus melalui perubahan dalam Undang-Undang (Rositawati, 2009)

Berdasarkan pengertian pajak daerah tersebut, maka dapat disimpulkan, bahwa pungutan yang dilakukan pemerintah daerah kepada masyarakatnya adalah sangat penting, karena :

1) Sebagai pendapatan daerah, maka pajak daerah merupakan dana yang sangat diperlukan oleh pemerintah daerah untuk menyelenggarakan pembangunan daerah.

2) Pengelolaan pajak dilaksanakan oleh Pemerintah Daerah.

3) Masyarakat secara langsung memberikan kontribusi yang besar bagi terselenggaranya pembangunan daerah.

4) Memberikan gambaran tentang kemandirian daerah yang bersangkutan dengan berkurangnya ketergantungan kepada Pemerintah Pusat.

Karena pentingnya Pajak Daerah tersebut, maka semua Pemerintah Daerah, Provinsi atau Kabupaten/Kota, harus benar-benar efektif dan efisien dalam melaksanakan pungutan pajak tersebut. Jenis dan objek Pajak harus benar-benar terdata dengan baik, karena jenis dan objek pajak adalah sumber utama efektifnya pungutan pajak.

\section{Jenis Pajak Daerah}

Pajak daerah adalah pajak yang pungutannya dilaksanakan oleh Pemerintah Daerah. Ada beberapa jenis pajak daerah yang harus dipungut dari masyarakat untuk kepentingan pembangunan daerah.

Jenis pajak daerah Provinsi dan pajak daerah Kabupaten/Kota berbeda, karena perbedaan dalam peraturan yang berlaku.

Jenis pajak daerah Propinsi adalah :

1) Pajak kendaraan bermotor

2) Bea balik nama kendaraan bermotor

3) Pajak bahan bakar kendaraan bermotor

4) Pajak air permukaan

5) Pajak rokok

Jenis pajak daerah Kabupaten/Kota adalah :

1) Pajak Hotel

2) Pajak Restoran

3) Pajak Hiburan

4) Pajak Reklame

5) Pajak Penerangan Jalan Umum 
6) Pajak Mineral Bukan Logam dan Batuan

7) Pajak Parkir

8) Pajak AirTanah

9) Pajak Sarang Burung Walet

10) Pajak Bumi dan Bangunan Perdesaan dan Perkotaan

11) Pajak Atas Perolehan Hak Atas Tanah dan/atau Bangunan.

Pajak yang jenisnya beragam pengelolaannya disesuaikan dengan kondisi dan jenis kegiatan daerah. Pungutan harus efektif dan efisien dengan cara intensifikasi dan ekstensifikasi pajak. Pada umumnya pajak daerah dilihat kontribusinya terhadap PAD, karena pajak adalah bagian dari PAD.

\section{Metode Penelitian}

Lokasi penelitian adalah Kota Banjarmasin. Obyek penelitian adalah pajak daerah sebagai bagian dari Pendapatan Asli Daerah Kota Banjarmasin.

Data yang digunakan dalam penelitian ini berupa data primer dan data sekunder. Data primer diperoleh melalui survei dan wawancara dengan berbagai pihak yang terkait dengan pemungutan dan pengelolaan pajak daerah.Data sekunder dikumpulkan melalui teknik dokumentasi berupa laporan Dinas Pendapatan Daerah Kota Banjarmasin, Badan Pusat Statistik, dan instansi terkait lainnya di Kota Banjarmasin.

Teknik analisa data yang digunakan adalah analisis deskriptif, analisis rasio efektivitas, dan analisis SWOT.

Analisis deskriptif digunakan untuk memaparkan dan menjelaskan tentang data dan kondisi yang adadengan menyajikan data dalam bentuk tabulasi dan dibandingkan dengan data lainnya.

Efektivitas pajak daerah menunjukkan kemampuan pemerintah daerah dalam mengumpulkan pajak daerah sesuai dengan jumlah penerimaan pajak daerah yang ditargetkan.Rasio Efektivitasdirumuskan sebagai berikut:

\section{$\frac{\text { RealisasiPajakDaerah }}{\text { TargetPajakDaerah }} \times 100 \%$}

Secara umum, nilai efektivitas dapat dikategorikan sebagai berikut:

- sangat efektif : $>100 \%$,

- efektif : 100\%,

- cukup efektif : 90-99\%,

- kurang efektif : 75-89\%, dan

- tidak efektif : $<75 \%$.

Analisis efisiensi pajak daerah untuk melihat kinerja pemerintah daerah dalam hal pemungutan pajak daerah. Efisiensi dikaitkan dengan bagaimana menghasilkan output maksimal dengan input minimal. Untuk mengukur efisiensi digunakanRasio Efisiensi dengan rumus sebagai berikut:

$$
\frac{\text { Biaya Pemungutan }}{\text { Realisasi Penerimaan }} \times 100 \%
$$

Kinerja pemerintah daerah dalam melakukan pemungutan pajak daerah dikategorikan efisien apabila ratio yang dicapai kurang dari 10\% (semakin kecil rasio ini semakin baik). Nilai efisiensi dapat dikategorikan sebagai berikut :

- Sangat efisien : $<10 \%$

- Efisien : $\quad 10-20 \%$

- Cukup efisien : $21-30 \%$

- Kurang efisien : $\quad 31-40 \%$

- Tidak efisien : $>40 \%$

Analisis SWOT adalah melakukan identifikasi terhadap faktor-faktor internal dan eksternal yang dianggap berpengaruh secara positif maupun secara negatif dalam hal pemungutan pajak daerah dalam rangka meningkatkan PAD yang dilakukan oleh dinas pendapatan daerahKota Banjarmasin. Hasil dari identifikasi ini akan menjadi dasar untuk kegiatan analisis berikutnya. Identifikasi faktor-faktor internal dan eksternal ini dilakukan dengan melakukan survey dan wawancara kepada pihak yang terkait dengan pengelolaan PAD khususnya Pajak Daerah di Kota Banjarmasin. Dari penilaian terhadap faktor-faktor internal dan eksternal, langkahselanjutnya adalah melakukan identifikasi unsur-unsur yang dikategorikan sebagaikekuatan (strength), kelemahan (weakness), kesempatan dan 
peluang (opportunity), serta ancaman (threat) yang dihadapi oleh dinas pendapatan daerah dalam hal pemungutan Pajak Daerah di Kota Banjarmasin.Selanjutnya merumuskan strategi dari kombinasi faktorfaktor internal dan eksternal yang terdiri dari:

1) Strategi Strength-Opportunity (SO); Interaksi kombinasi strategi SO: yaitu suatu strategi yang menggunakan kekuatan untuk memanfaatkan peluang;

2) Strategi Strength-Threat (ST); Interaksi kombinasi strategi ST: yaitu suatu strategi yang menggunakan kekuatan untuk mengatasi ancaman;

3) Strategi Weakness-Opportunity (WO); Interaksi kombinasi strategi WO: yaitu suatu strategi yang meminimalkan kelemahan untuk memanfaatkan peluang;

4) Strategi Weakness-Threat (WTT) Interaksi kombinasi strategi WT: yaitu suatu strategi yang meminimalkan kelemahan untuk mengatasi ancaman.
Hasil dan Pembahasan

Pendapatan Asli Daerah

Pendapatan Asli Daerah merupakan salah satu sumber pendanaan pelaksanaan pemerintahan daerah selain Dana Perimbangan, Pinjaman Daerah dan Pendapatan Lain-lain yang sah. Semakin besar Pendapatan Asli Daerah (PAD) suatu daerah, maka semakin besar kemandirian daerah tersebut dalam menyelenggarakan pembangunan di daerahnya.

Perkembangan Pendapatan Asli Daerah (PAD) Kota Banjarmasin selama lima tahun terakhir (2011-2015) menunjukkan peningkatan yang cukup signifikan. Hal ini menunjukkan bahwa kemampuan Kota Banjarmasin dalam pendanaan proses pembangunan semakin baik. Tabel 1 menunjukkan bahwa dilihat dari kontribusi PAD terhadap pendapatan total semakin meningkat dari tahun ke tahun, kecuali tahun 2012 yang menunjukkan kontribusi yang sedikit menurun.

Tabel 1. Perkembangan Kontribusi Pendapatan Asli Daerah (PAD) Terhadap Total Pendapatan Kota Banjarmasin Tahun 2011 - 2015

\begin{tabular}{cccc}
\hline Tahun & $\begin{array}{c}\text { Pendapatan Asli } \\
\text { Daerah } \\
\mathbf{( R p )}\end{array}$ & $\begin{array}{c}\text { Total Pendapatan } \\
\text { (Rp) }\end{array}$ & $\begin{array}{c}\text { Kontribusi } \\
\text { PADterhadap Total } \\
\text { Pendapatan (\%) }\end{array}$ \\
\hline 2011 & 118.554 .981 .543 & 933.376 .048 .907 & 12,70 \\
2012 & 138.086 .121 .907 & 1.198 .365 .063 .456 & 11,52 \\
2013 & 167.313 .762 .017 & 1.285 .106 .361 .571 & 13,02 \\
2014 & 216.427 .691 .790 & 1.432 .589 .208 .704 & 15,11 \\
2015 & 225.821 .059 .656 & 1.405 .907 .057 .803 & 16,06 \\
\hline
\end{tabular}

Sumber: Dinas Pendapatan Daerah Kota Banjarmasin, diolah kembali

Pendapatan Asli Daerah (PAD) terdiri dari Pajak Daerah, Retribusi Daerah, Hasil Pengelolaan Kekayaan Daerah yang Dipisahkan, dan lain-lain Pendapatan Asli Daerah yang Sah. Dari keempat komponen tersebut, sumbangan terbesar adalah dari Pajak Daerah yang diikuti oleh Retribusi Daerah. Dengan demikian, penerimaan
Pajak Daerah dan Retribusi Daerah diharapkan nantinya dapat memberikan kontribusi yang positif terhadap Pendapatan Asli Daerah dalam hal pencapaian dan pemerataan kesejahteraan masyarakat. Rata-rata kontribusi masingmasing komponen Pendapatan Asli Daerah dapat dilihat pada Tabel 2 berikut: 
Tabel 2. Rata-Rata Realisasi Pendapatan Asli Daerah Kota Banjarmasin Tahun $2011-2015$

\begin{tabular}{clrr}
\hline NO & \multicolumn{1}{c}{ Jenis Penerimaan } & \multicolumn{1}{c}{$\begin{array}{c}\text { Jumlah } \\
(\mathbf{R p .})\end{array}$} & $\begin{array}{c}\text { Kontribusi } \\
\mathbf{( \% )}\end{array}$ \\
\hline 1 & Pajak Daerah & 108.485 .724 .377 & 62,62 \\
2 & Retribusi Daerah & 28.990 .143 .119 & 16,73 \\
3 & Hasil Pengelolaan Kekayaan Daerah yang & & \\
& Dipisahkan & 10.154 .319 .806 & 5,86 \\
4 & Lain-lain Pendapatan Asli Daerah yang Sah & 25.610 .536 .080 & 14,78 \\
\hline & $\quad$ Pendapatan Asli Daerah & 173.240 .723 .382 & 100,00 \\
\hline
\end{tabular}

Sumber: Dinas Pendapatan Daerah Kota Banjarmasin, diolah kembali

Dari Tabel 2 dapat dilihat bahwa ratarata kontribusi terbesar adalah Pajak Daerah, yaitu sebesar 62,62\%, diikuti oleh Retribusi Daerah 16,73\%, Hasil Pengelolaan Kekayaan Daerah yang Dipisahkan $\quad 14,78 \%$ dan Lain-lain Pendapatan Asli Daerah yang Sah hanya sebesar 5,86\%. Dengan kontribusi Pajak Daerah yang sangat besar terhadap Pendapatan Asli Daerah (PAD), maka efisiensi dan efektivitas dalam hal penggalian potensi dan pemungutan Pajak Daerah menjadi hal yang sangat penting dalam upaya meningkatkan Pendapatan Asli Daerah.

Perkembangan realisasi Pendapatan Asli Daerah (PAD) tahun 2011 - 2015 menurut jenis penerimaan dapat dilihat pada Gambar 1. Dapat dilihat bahwa keempat komponen yang berkontribusi dalam PAD menunjukkan peningkatan dari tahun ke tahun, kecuali untuk Hasil Pengelolaan Kekayaan Daerah yang Dipisahkan menunjukkan penurunan pada tahun 2012, kemudian meningkat kembali tahun 2013, meskipun belum dapat menyamai penerimaan di tahun 2011.

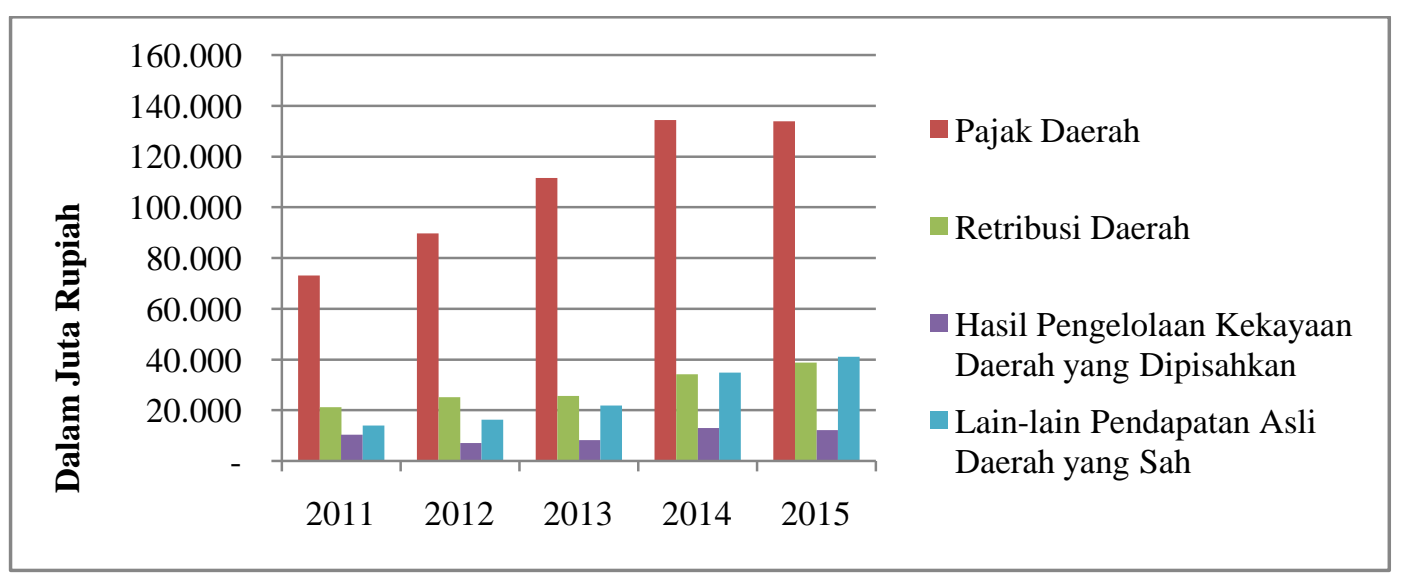

Sumber: Dinas Pendapatan Daerah Kota Banjarmasin, diolah kembali

\section{Gambar 1. Perkembangan Realisasi Pendapatan Asli Daerah Kota Banjarmasin Menurut Jenis Penerimaan Tahun 2011 - 2015}

Target dan realisasi Pendapatan Asli Daerah Kota Banjarmasin tahun 2011 2015 terus mengalami peningkatan, akan tetapi bila dilihat dari pencapaian cenderung mengalami fluktuasi. Rata-rata target dan realisasi Pendapatan Asli Daerah (PAD) Kota Banjarmasin dapat dilihat pada Tabel 3 berikut: 
Tabel 3. Rasio Efektivitas Pendapatan Asli Daerah Kota Banjarmasin Tahun $2011-2015$

\begin{tabular}{lrrr}
\hline \multicolumn{1}{c}{ Jenis Penerimaan } & Target (Rp.) & Realisasi (Rp.) & $\begin{array}{c}\text { Rasio } \\
\text { Efektivitas } \\
\mathbf{( \% )}\end{array}$ \\
\hline Pajak Daerah & 107.819 .440 .035 & 108.485 .724 .377 & 101,49 \\
Retribusi Daerah & 25.191 .523 .720 & 28.990 .143 .119 & 115,74 \\
$\begin{array}{l}\text { Hasil Pengelolaan Kekayaan } \\
\text { Daerah yang Dipisahkan }\end{array}$ & 13.913 .710 .000 & 10.154 .319 .806 & 73,94 \\
Lain-lain Pendapatan Asli Daerah & & & 126,31 \\
yang Sah & 22.561 .081 .281 & 25.610 .536 .080 & 103,34 \\
\hline \multicolumn{1}{c}{ Pendapatan Asli Daerah } & 169.485 .755 .036 & 173.240 .723 .382 & \\
\hline
\end{tabular}

Sumber: Dinas Pendapatan Daerah Kota Banjarmasin, diolah kembali

Terlihat dari Tabel 3 bahwa secara rata-rata tahun 2011 - 2015 realisasi PAD sudah melebihi target yang diharapkan, yaitu $103,34 \%$, akan tetapi bila dilihat dari tahun ke tahun, maka terjadi penurunan capaian di tahun 2015 di mana realisasi hanya mencapai $91,76 \%$. Dari keempat komponen PAD hanya Hasil Pengelolaan Kekayaan Daerah yang Dipisahkan saja rata-rata realisasinya di bawah target yang ditetapkan, yaitu hanya $73,94 \%$.

Perkembangan target dan realisasi Pendapatan Asli Daerah dapat dilihat pada Gambar 2 Selama tahun 2011 - 2014, realisasi PAD sudah dapat melewati target yang ditetapkan, kecuali pada tahun 2015 target masih belum tercapai.

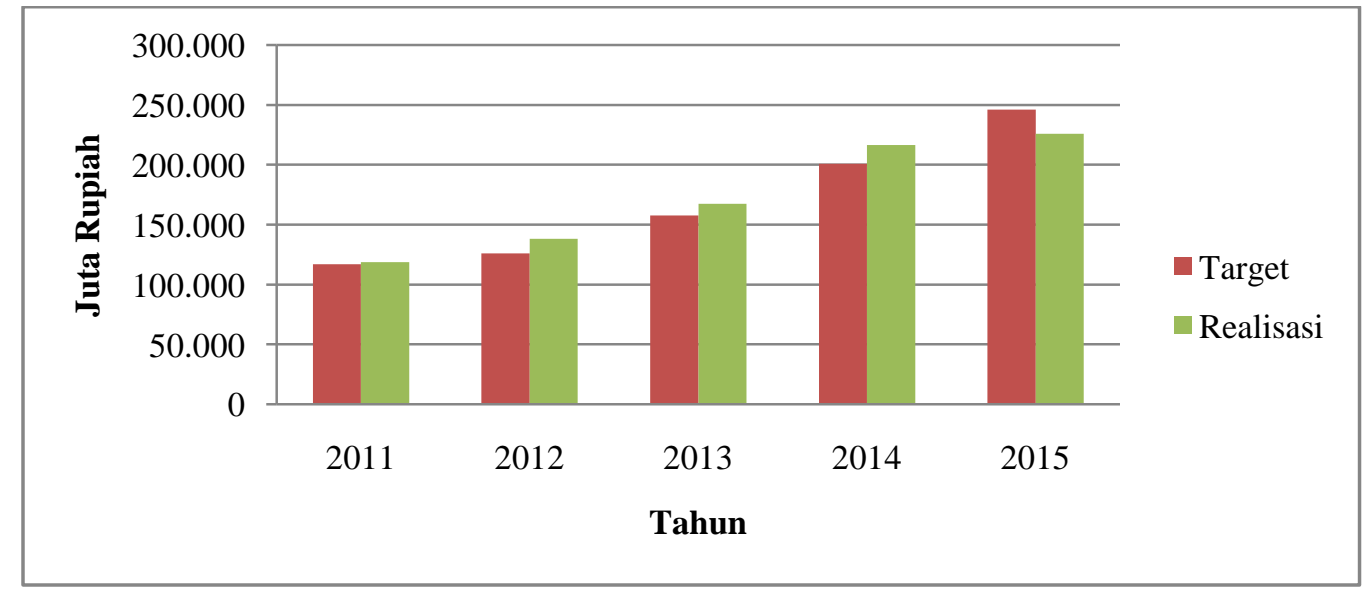

Sumber: Dinas Pendapatan Daerah Kota Banjarmasin, diolah kembali

\section{Gambar 2. Perkembangan Target dan Realisasi Pendapatan Asli Daerah Kota Banjarmasin Tahun 2011 - 2015}

\section{Pajak Daerah}

Pajak Daerah merupakan faktor penting dalam meningkatkan Pendapatan Asli Daerah (PAD) dilihat dari kontribusinya yang sangat dominan di dalam penerimaan PAD, yaitu rata-rata 62,91 \%. Perkembangan kontribusi dan pertumbuhan Pajak Daerah Kota Banjarmasin dapat dilihat pada Tabel 4 berikut: 
Tabel 4. Perkembangan Realisasi, Kontribusi terhadap PAD, dan Pertumbuhan Pajak Daerah Kota Banjarmasin Tahun 2011 - 2015

\begin{tabular}{cccc}
\hline Tahun & Realisasi (Rp.) & $\begin{array}{c}\text { Kontribusi Terhadap } \\
\text { PAD (\%) }\end{array}$ & $\begin{array}{c}\text { Pertumbuhan } \\
\mathbf{( \% )}\end{array}$ \\
\hline 2011 & 73.061 .359 .184 & 61,63 & 70,06 \\
2012 & 89.610 .952 .329 & 64,89 & 22,65 \\
2013 & 111.508 .975 .587 & 66,65 & 24,44 \\
2014 & 134.413 .962 .588 & 62,11 & 20,54 \\
2015 & 133.833 .372 .198 & 59,27 & $(0,43)$ \\
\hline Rata-rata & 108.485 .724 .377 & 62,91 & 27,45 \\
\hline
\end{tabular}

Sumber : Dinas Pendapatan Daerah Kota Banjarmasin, Berbagai Tahun, diolah kembali

Perkembangan realisasi penerimaan Pajak Daerah dari tahun ke tahun mengalami peningkatan, yaitu mengalami peningkatan sebesar 70,06\% (2011), $22,65 \%$ (2012), $24,44 \%$ (2013) dan 20,54\% (2014), kecuali tahun 2015, di mana realisasi mengalami penurunan sebesar $0,43 \%$.

\section{Rasio Efektivitas Pajak Daerah}

Data target dan realisasi pajak daerah Kota Banjarmasin tahun 2011 - 2015 menunjukkan peningkatan dari tahun ke tahun, akan tetapi bila dilihat dari pencapaian realisasi terhadap target yang ditetapkan atau rasio efektivitas pajak daerah menunjukkan fluktuasi.

Tahun 2011 dan 2015 realisasi penerimaan Pajak Daerah masih di bawah target yang ditetapkan atau hanya memenuhi kriteria kurang efektif. Tahun 2011 target yang ditetapkan adalah Rp. 73.765.810.000,- sementara realisasi hanya
Rp. 73.061.359.184,- atau rasio efektivitas hanya 99,05\% (cukup efektif). Begitu pula untuk tahun 2015, di mana rasio efektivitas hanya 91,19 \% (cukup efektif), yaitu realisasi Rp.133.833.372.198,- padahal target yang ditetapkan adalah Rp.146.771.048.177,--.

Tahun 2012 - 2014, target yang ditetapkan sudah dapat dicapai, meskipun realisasi yang dicapai hanya sedikit melampaui target yang ditetapkan. Secara rinci target dan realisasi Pajak Daerah Kota Banjarmasin dapat dilihat dari Tabel 2. Dari Tabel 5terlihat bahwa di tahun 2012 - 2014 realisasi sudah melampaui target yang ditetapkan, sementara pada tahun 2015 justru realisasi masih jauh di bawah target yang ditetapkan, yaitu hanya mencapai 91,19 \%. Hal ini menunjukkan bahwa masih banyak potensi Pajak Daerah yang belum terpungut dengan baik.

Tabel 5. Rasio Efektivitas Pajak Daerah Kota Banjarmasin Tahun 2011 - 2015

\begin{tabular}{cccrl}
\hline Tahun & $\begin{array}{c}\text { Target } \\
\text { (Rupiah) }\end{array}$ & $\begin{array}{l}\text { Realisasi } \\
\text { (Rupiah) }\end{array}$ & $\begin{array}{c}\text { Rasio } \\
\text { Efektivitas(\%) }\end{array}$ & Kriteria \\
\hline 2011 & 73.765 .810 .000 & 73.061 .359 .184 & 99,05 & Cukup Efektif \\
2012 & 81.129 .410 .000 & 89.610 .952 .329 & 110,45 & Sangat Efektif \\
2013 & 110.766 .622 .000 & 111.508 .975 .587 & 100,67 & Sangat Efektif \\
2014 & 126.664 .310 .000 & 134.413 .962 .588 & 106,12 & Sangat Efektif \\
2015 & 146.771 .048 .177 & 133.833 .372 .198 & 91,19 & Cukup Efektif \\
\hline Rata-rata & 107.819 .440 .035 & 108.485 .724 .377 & 101,49 & Sangat Efektif \\
\hline
\end{tabular}

Sumber : Dinas Pendapatan Daerah Kota Banjarmasin, Berbagai Tahun 
Pajak daerah Kota Banjarmasin terdiri dari 9 (sembilan) objek pajak, yaitu 1) Pajak Hotel, 2) Pajak Restoran/ Rumah Makan, 3) Pajak Hiburan, 4) Pajak Reklame, 5) Pajak Penerangan Jalan Umum (PPJU)/PLN, 6) Pajak Parkir, 7) Pajak Sarang Burung Walet, 8) Pajak Bumi dan Bangunan (PBB) Perdesaan dan Perkotaan, dan 9) Pajak Bea Perolehan Hak Atas Tanah dan Bangunan (BPHTB). PBB perdesaan dan perkotaan merupakan objek pajak yang dialihkan pemungutannya dari pemerintah pusat ke pemerintah daerah yang dimulai sejak tahun 2013.

Dari 9 (sembilan) jenis Pajak Daerah tersebut maka yang berpotensi dalam meningkatkan Pendapatan Asli Daerah dilihat dari rata-rata kontribusi terhadap total penerimaan Pajak Daerah Tahun 2011 - 2015 adalah Pajak Restoran dengan ratarata kontribusi 22,67\%, Pajak Penerangan Jalan Umum (PPJU) dengan rata-rata kontribusi 24,89\%, Pajak Pajak Bumi dan Bangunan Perdesaan dan Perkotaan (PBB $\mathrm{PP})$ dengan rata-rata kontribusi 15,74\%, dan Pajak Bea Perolehan Hak Atas Tanah dan Bangunan (BPHTB) dengan rata-rata kontribusi $15,40 \%$. Sementara yang kurang potensial adalah Pajak Reklame, Pajak Parkir dan Pajak Sarang Burung Walet, dengan kontribusi masih di bawah 5\%. Rata-rata kontribusi masing-masing jenis pajak terhadap total penerimaan Pajak Daerah dapat dilihat pada Tabel 6.

Tabel 6. Rata-rata Kontribusi Pajak Daerah Menurut Jenis Pajak Kota Banjarmasin Tahun $2011-2015$

\begin{tabular}{clrr}
\hline No. & \multicolumn{1}{c}{ Jenis Penerimaan } & \multicolumn{1}{c}{$\begin{array}{c}\text { Realisasi } \\
(\mathbf{R} \mathbf{)})\end{array}$} & $\begin{array}{c}\text { Kontribusi } \\
\mathbf{( \% )}\end{array}$ \\
\hline 1 & Pajak Hotel & 13.971 .243 .250 & 12,88 \\
2 & Pajak Restoran/Rumah Makan & 24.592 .344 .182 & 22,67 \\
3 & Pajak Hiburan & 8.756 .987 .804 & 8,07 \\
4 & Pajak Reklame & 4.399 .958 .493 & 4,06 \\
5 & Pajak Penerangan Jalan Umum (PPJU)/ PLN & 27.005 .184 .549 & 24,89 \\
6 & Pajak Parkir & 2.456 .845 .468 & 2,26 \\
7 & Pajak Sarang Burung Walet & 351.771 .330 & 0,32 \\
8 & PBB Perdesaan \& Perkotaan (PBB-PP) & 17.079 .671 .200 & 15,74 \\
9 & Pajak Bea Perolehan Hak Atas Tanah \& & & \\
& Bangunan (BPHTB) & 16.703 .586 .581 & 15,40 \\
\hline & Jumlah Pajak Daerah & $\mathbf{1 0 8 . 4 8 5 . 7 2 4 . 3 7 7}$ & $\mathbf{1 0 0 , 0 0}$ \\
\hline
\end{tabular}

Sumber : Dinas Pendapatan Daerah Kota Banjarmasin, diolah kembali

Keempat jenis pajak yang dominan dalam kontribusinya terhadap total penerimaan Pajak Daerah, karena objek pajak dari keempat jenis pajak tersebut sangat jelas dasar perhitungannya dan pemungutannya. Seperti Pajak Restoran/Rumah Makan yang langsung dibayar oleh konsumen melalui pemilik Restoran atau Rumah Makan, Pajak Penerangan Jalan Umum melalui rekening listrik yang dibayarkan pelanggan. Pajak Bumi dan Bangunan Perdesaan dan
Perkotaan merupakan jenis pajak baru yang kewenanganpemungutannya diberikan kepada daerah.

Dilihat dari pengelolaan Pajak Daerah, penerimaan Pajak Daerah secara total sudah dapat melampaui target yang ditetapkan, akan tetapi bila dicermati secara rinci data target dan realisasi Pajak Daerah menurut jenisnya tidak semuanya mencapai target yang diharapkan. Rata-rata target dan realisasi menurut jenis pajak selama tahun 2011 - 2015 disajikan pada Tabel 7. 
Tabel 7. Rasio Efektivitas Pajak Daerah Menurut Jenis Pajak Kota Banjarmasin Tahun $2011-2015$

\begin{tabular}{|c|c|c|c|c|c|}
\hline No. & Jenis Pajak & $\begin{array}{c}\text { Target } \\
\text { (Rp. Juta) }\end{array}$ & $\begin{array}{l}\text { Realisasi } \\
\text { (Rp. Juta) }\end{array}$ & $\begin{array}{c}\text { Rasio } \\
\text { Efektivitas } \\
(\%) \\
\end{array}$ & Kriteria \\
\hline 1 & Pajak Hotel & $14.407,80$ & $13.971,24$ & 103,22 & Sangat Efektif \\
\hline 2 & $\begin{array}{l}\text { Pajak } \\
\text { Restoran/Rumah } \\
\text { Makan }\end{array}$ & 71,62 & 92,34 & 118,44 & Efektif \\
\hline 3 & Pajak Hiburan & $9.112,13$ & $8.756,99$ & 99,07 & Cukup Efektif \\
\hline 4 & Pajak Reklame & $4.972,45$ & $4.399,96$ & 93,96 & Cukup Efektif \\
\hline 5 & $\begin{array}{l}\text { Pajak Penerangan Jalan } \\
\text { Umum (PPJU) / PLN }\end{array}$ & $23.780,81$ & $27.005,18$ & 114,07 & Sangat Efektif \\
\hline 6 & Pajak Parkir & $2.394,62$ & $2.456,85$ & 102,13 & Sangat Efektif \\
\hline 7 & $\begin{array}{l}\text { Pajak Sarang Burung } \\
\text { Walet }\end{array}$ & 930,00 & 351,77 & 48,28 & Tidak Efektif \\
\hline 8 & $\begin{array}{l}\text { PBB Perdesaan dan } \\
\text { Perkotaan (PBB-PP) }\end{array}$ & $16.250,00$ & $17.079,67$ & 105,41 & Sangat Efektif \\
\hline 9 & $\begin{array}{l}\text { Pajak Bea Perolehan } \\
\text { Hak Atas Tanah \& } \\
\text { Bangunan (BPHTB) }\end{array}$ & $21.000,00$ & $16.703,59$ & 79,34 & Kurang Efektif \\
\hline \multicolumn{2}{|c|}{ Rata-rata Pajak Daerah } & $107.819,44$ & $108.485,72$ & 101,49 & Sangat Efektif \\
\hline
\end{tabular}

Sumber : Dinas Pendapatan Daerah Kota Banjarmasin, diolah kembali

Dari 9 (sembilan) jenis pajak yang menunjukkan hasil pencapaian melebihi target yang ditetapkan rata-rata selama tahun 2011 - 2015 atau menunjukkan kriteria sangat efektif adalah Pajak Hotel $(103,22 \%)$, Pajak Restoran/Rumah Makan $(118,44 \%)$, PPJU/PLN (114,77\%), Pajak Parkir (102,13 \%), dan PBB-P2 (105,41 \%). Realisasi penerimaan pajak yang masih di bawah target yang ditetapkan adalah Pajak Hiburan dengan rata-rata realisasi hanya 99,07\% (cukup efektif) dari target yang ditetapkan, Pajak Reklame 93,96\% (cukup efektif), begitu pula halnya Pajak BPHTB hanya 79,34\% (kurang efektif) dan Pajak Sarang Burung Walet bahkan masih di bawah 50\%, yaitu 48,28\% atau tidak efektif (lihat Tabel 5).

\section{Analisis Efisiensi Pajak Daerah}

Kinerja pemerintah daerah dalam pengelolaan pajak daerah juga dapat dilihat dari rasio efisiensi. Secara umum efisiensi menunjukkan perbandingan antara input yang digunakan dengan output yang diperoleh. Semakin kecil angka perbandingan antara input dan output, semakin efisien. Dalam hal pengelolaan Pajak Daerah efisiensi diukur dengan rumus rasio biaya pemungutan Pajak Daerah dengan realisasi penerimaan Pajak Daerah dalam persentase.

Perkembangan rasio efisiensi Pajak Daerah Kota Banjarmasin tahun 2011 2015 menunjukkan bahwa secara keseluruhan berada di bawah angka 10\% (lihat Tabel 8). Tabel 8 menunjukkan pada tahun 2011 rasio efisiensi 5,02\% (sangat efisien) dan di tahun 2012 angka itu meningkat menjadi $7,18 \%$, yang berarti bahwa tingkat efisiensi menurun. Sementara pada tahun 2013-2015 menunjukkan angka rasio efisiensi yang menurun dibandingkan dengan tahun 2012.

Tabel 8. Perkembangan Rasio Efisiensi Pajak Daerah Kota Banjarmasin Tahun $2011-2015$ 


\begin{tabular}{|c|r|r|r|l|}
\hline Tahun & $\begin{array}{c}\text { Realisasi } \\
\text { Penerimaan } \\
\text { (Rp. Juta) }\end{array}$ & $\begin{array}{c}\text { Biaya } \\
\text { Pemungutan } \\
\text { (Rp. Juta) }\end{array}$ & $\begin{array}{c}\text { Rasio } \\
\text { Efisiensi } \\
\mathbf{( \% )}\end{array}$ & Kategori \\
\hline $\mathbf{2 0 1 1}$ & $73.061,36$ & $3.665,00$ & 5,02 & Sangat Efisien \\
\hline $\mathbf{2 0 1 2}$ & $89.610,95$ & $6.431,67$ & 7,18 & Sangat Efisien \\
\hline $\mathbf{2 0 1 3}$ & $111.508,98$ & $3.192,14$ & 2,86 & Sangat Efisien \\
\hline $\mathbf{2 0 1 4}$ & $134.413,96$ & $4.068,71$ & 3,03 & Sangat Efisien \\
\hline $\mathbf{2 0 1 5}$ & $133.833,37$ & $2.977,64$ & 2,22 & Sangat Efisien \\
\hline Rata-rata & $\mathbf{1 0 8 . 4 8 5 , 7 2}$ & $\mathbf{4 . 0 6 7 , 0 3}$ & $\mathbf{3 , 7 5}$ & Sangat Efisien \\
\hline
\end{tabular}

Sumber : Dinas Pendapatan Daerah Kota Banjarmasin, diolah kembali

Rata-rata selama tahun 2011 - 2015 rasio efisiensi Pajak Daerah apabila dirinci menurut sumbernya menunjukkan bahwa hampir seluruhnya juga sangat efisien kecuali untuk Pajak Bumi dan Bangunan
Perdesaan dan Perkotaan (PBB-PP) dan Pajak BPHTB termasuk dalam kategori efisien dengan angka rasio efisiensi masingmasing $15,46 \%$ dan $14,30 \%$. Lebih jelasnya bisa dilihat pada Tabel 9 berikut.

Tabel 9. Rata-rata Rasio Efisiensi Pajak Daerah Kota Banjarmasin Menurut Jenisnya Tahun $2011-2015$

\begin{tabular}{|r|l|r|r|r|l|}
\hline No. & \multicolumn{1}{|c|}{$\begin{array}{c}\text { Jenis Pajak } \\
\text { Daerah }\end{array}$} & $\begin{array}{c}\text { Realisasi } \\
\text { Penerimaan } \\
\text { (Rp. Juta) }\end{array}$ & $\begin{array}{c}\text { Biaya } \\
\text { Pemungutan } \\
\text { (Rp. Juta) }\end{array}$ & $\begin{array}{c}\text { Rasio } \\
\text { Efisiensi } \\
\mathbf{( \% )}\end{array}$ & Kategori \\
\hline 1 & Pajak Hotel & $13.971,24$ & 151,76 & 1,09 & Sangat Efisien \\
\hline 2 & Pajak Restoran & $24.592,34$ & 223,75 & 0,91 & Sangat Efisien \\
\hline 3 & Pajak Hiburan & $8.756,99$ & 116,84 & 1,33 & Sangat Efisien \\
\hline 4 & Pajak Reklame & $4.399,96$ & 31,49 & 0,72 & Sangat Efisien \\
\hline 5 & Pajak PJU / PLN & $27.005,18$ & 184,23 & 0,68 & Sangat Efisien \\
\hline 6 & Pajak Parkir & $2.456,85$ & 16,97 & 0,69 & Sangat Efisien \\
\hline & Pajak Sarang & & & & \\
\hline 7 & Burung Walet & 351,77 & 2,53 & 0,72 & Sangat Efisien \\
\hline 8 & PBB-PP & $10.247,80$ & $1.584,80$ & 15,46 & Efisien \\
\hline 9 & Pajak BPHTB & $16.703,59$ & $2.388,59$ & 14,30 & Efisien \\
\hline \multicolumn{2}{|c|}{ PAJAK DAERAH } & $\mathbf{1 0 8 . 4 8 5 , 7 2}$ & $\mathbf{4 . 0 6 7 , 0 3}$ & $\mathbf{3 , 7 5}$ & Sangat Efisien \\
\hline
\end{tabular}

Sumber : Dinas Pendapatan Daerah Kota Banjarmasin, diolah kembali

\section{Analisis SWOT}

Pemerintah Daerah Kota Banjarmasin selama ini melalui Dinas Pendapatan Daerah selalu berupaya untuk terus meningkatkan penerimaan Pendapatan Asli Daerah (PAD).

Meningkatkan Pendapatan Asli Daerah hendaknya tidak harus ditempuh dengan cara menaikkan tarif saja, tetapi yang lebih penting dengan memperbaiki atau menyempurnakan administrasi, sistem dan prosedur serta organisasi dari Dinas Pendapatan Daerah yang ada sekarang. Seperti yang dikemukakan Sobandi (2003), meskipun UU Nomor 34 Tahun 2000 (atau sekarang diubah menjadi UU Nomor 28 Tahun 2009) memberikan keleluasaan kepada daerah untukmenciptakan (menggali) sumber pendapatan baru (differsification) terutama yangberbentuk 
pajak, tidak berarti daerah bebas menciptakannya tanpa memperhatikanberbagai faktor yang terkait terutama aspek normatif, argumentasi teoritis, sertaimplikasinya terhadap aktivitas perekonomian dan kesejahteraan masyarakat baik padajangka pendek, jangka menengah, ataupun jangka panjang.

Berkenaan dengan permasalahanpermasalahan pelayananDinas Pendapatan Daerah Kota Banjarmasin dalam upaya meningkatkan Pendapatan Asli Daerah khususnya pada Sektor Pajak Daerah dan Retribusi Daerah, ada beberapa faktorfaktor yang mempengaruhinya yaitu lingkungan eksternal dan lingkungan internal. Lingkungan internal adalah analisa intern organisasi dalam rangka menilai atau mengidentifikasikan kekuatan dan kelemahan organisasi. Sementara lingkungan eksternal adalah suatu kekuatan yang berada diluar organisasi dimana organisasi tidak mempunyai pengaruh sama sekali terhadapnya, akan tetapi perubahan yang terjadi pada lingkungan itu akan turut mempengaruhi kinerja organisasi tersebut.Analisis lingkungan eksternal dan internal organisasi ini dikenal dengan Analisis SWOT (Strength, Weakness, Opportunity, Threat). Analisis SWOT Dinas Pendapatan Daerah (Dispenda) Kota Banjarmasin disajikan pada Tabel 10.

\section{Tabel 10. Analisis SWOT}

\begin{tabular}{|c|c|}
\hline Lingkungan Internal & Lingkungan Eksternal \\
\hline Kekuatan (Strength): & Peluang (Opportunity): \\
\hline 1. Tersedianya sumber daya manusia (SDM) & 1. UU No. 23 Tahun 2014 tentang \\
\hline $\begin{array}{l}\text { 2. Tersedianya sarana dan prasarana yang } \\
\text { memadai }\end{array}$ & $\begin{array}{l}\text { 2. UU No. } 28 \text { Tahun } 2009 \text { tentang Pajak } \\
\text { dan Retribusi Daerah }\end{array}$ \\
\hline $\begin{array}{l}\text { 3. Adanya komitmen organisasi untuk } \\
\text { mencapai tujuan }\end{array}$ & $\begin{array}{l}\text { 3. Tujuan politik Pemerintah Daerah } \\
\text { Kota Banjarmasin }\end{array}$ \\
\hline 4. Adanya program kerja yang tepat sasaran & 4. Semakin bertambahnya wajib pajak \\
\hline Kelemahan (Weakness): & Ancaman (Threat): \\
\hline $\begin{array}{l}\text { 1. Masih lemahnya kualitas Sumber Daya } \\
\text { Manusia (SDM) }\end{array}$ & $\begin{array}{l}\text { 1. Kurangnya kesadaran masyarakat } \\
\text { dalam membayar pajak }\end{array}$ \\
\hline $\begin{array}{l}\text { 2. Masih kurangnya data yang valid sesuai } \\
\text { dengan potensi riil }\end{array}$ & 2. Krisis ekonomi \\
\hline $\begin{array}{l}\text { 3. Belum optimalnya pelayanan terhadap } \\
\text { masyarakat }\end{array}$ & $\begin{array}{l}\text { 3. Krisis kepercayaan kepada pemerintah } \\
\text { 4. Tuntutan masyarakat }\end{array}$ \\
\hline 4. Lemahnya birokrasi & \\
\hline
\end{tabular}

\section{Strategi Pengelolaan Pajak Daerah}

Dari Analisis SWOT di atas, maka strategi yang harus dilakukan dalam rangka meningkatkan Pendapatan Asli Daerah terutama dari sektor Pajak Daerah adalah sebagai berikut:

1) Memberdayakan personil yang tersedia untuk melakukan pemungutan pajak dan retribusi daerah lebih intensif

2) Meningkatkan kualitas Sumber Daya Manusia, baik dalam hal pelayanan maupun kinerja, melalui pendidikan dan pelatihan

3) Membuat program kerja sesuai dengan tujuan dan sasaran yang diharapkan

4) Mengalokasikan dana untuk sosialisasi dan publikasi tentang pelayanan dan kesadaran masyarakat akan pentingnya pajak dan retribusi yang mereka bayarkan untuk pembiayaan pembangunan dan peningkatan pelayanan masyarakat. 
5) Meningkatkan penggunaan teknologi informasi yang lebih baik sehingga meningkatkan kemampuan dalam pendataan potensi pajak dan retribusi yang lebih valid.

6) Penyederhanaan tahapan birokrasi serta peningkatan layanan online dalam hal pembayaran pajak sehingga dapat menarik minat masyarakat untuk membayar pajak.

\section{Penutup}

\section{Simpulan}

Berdasarkan hasil dan pembahasan dalam bab sebelumnya, maka dapat diambil beberapa kesimpulan sebagai berikut:

Perkembangan Pendapatan Asli Daerah (PAD) Kota Banjarmasin selama lima tahun terakhir (2011 - 2015) menunjukkan peningkatan yang cukup signifikan.Pajak Daerah merupakan sumber terbesar Pendapatan Asli Daerah (PAD), sehingga efisiensi dan efektivitas dalam hal penggalian potensi dan pemungutan Pajak Daerah menjadi hal yang sangat penting dalam upaya meningkatkan Pendapatan Asli Daerah.

Perkembangan Realisasi pajak daerah Kota Banjarmasin tahun 2011-2015 menunjukkan peningkatan dari tahun ke tahun, akan tetapi bila dilihat dari pencapaian realisasi terhadap target yang ditetapkan. Tahun 2011 dan 2015 realisasi penerimaan Pajak Daerah masih di bawah target yang ditetapkan atau rasio efektivitas termasuk cukup efektif, hal ini menunjukkan bahwa masih banyak potensi Pajak Daerah yang belum terpungut dengan baik.

Pajak Daerah potensial adalah Pajak Restoran, Pajak Penerangan Jalan Umum (PPJU), Pajak Bumi dan Bangunan Perdesaan dan Perkotaan (PBB PP) dan Pajak Bea Perolehan Hak Atas Tanah dan Bangunan (BPHTB). Sementara yang kurang potensial adalah Pajak Reklame, Pajak Parkir dan Pajak Sarang Burung Walet.

Dari segi pengelolaan masih banyak Pajak Daerah yang realisasinya masih di bawah target yang ditetapkan, yaitu Pajak Hiburan, Pajak
Reklame, Pajak BPHTB, dan Pajak Sarang Burung Walet.

Strategi untuk meningkatkan Pendapatan Asli Daerah (PAD) adalah (1) melakukan sosialisasi dan publikasi tentang pelayanan dan kesadaran masyarakat akan pentingnya pajak dan retribusi (2) Meningkatkan penggunaan teknologi informasi yang lebih baik sehingga meningkatkan kemampuan dalam pendataan potensi pajak dan retribusi yang lebih valid, (3) Menyederhanakan tahapan birokrasi serta peningkatan layanan online dalam hal pembayaran pajak sehingga dapat menarik minat masyarakat untuk membayar pajak.

\section{Saran}

Perlunya pendataan ulang kembali objek pajak sehingga target yang ditetapkan lebih sesuai dengan potensi riil dan upaya yang lebih intensif dalam melakukan pungutan.

Perlunya melakukan sosialisasi dan publikasi mengenai pelayanan dan pentingnya pajak yang dibayarkan masyarakat untuk pembangunan daerah.

Perlunya penyederhanaan tahapan dalam pembayaran pajak serta peningkatan layanan online yang dapat menarik minat masyarakat untuk melakukan kewajibannya membayar pajak.

Perlunya pengawasan secara berkala kepada pengusaha hotel dan restoran/rumah makan dan pemberian sanksi untuk yang lalai akan kewajibannya dalam hal penyetoran pajak yang telah dipungut dari konsumen yang mendapatkan layanan.

\section{Daftar Pustaka}

Ekonomi Kota Banjarmasin. BPS. Banjarmasin.

Rositawati, Rita. 2009. Sistem Pemungutan Pajak Daerah dalam Otonomi Daerah (Studi Kasus di Kabupaten Bogor). Tesis. Program Magister Ilmu Hukum. Pascaarjana Universitas Diponegoro. 
31 AT-TARADHI Jurnal Ilmu Ekonomi, Volume 8, Nomor 1, Juni 2017, blm. 17-31.

Saleh, Muhammad. 2005. Kajian Potensi Pendapatan Asli Daerah (dari Pajak Daerah) Dalam Rangka Peningkatan PAD Kabupaten Banjar. Laporan Penelitian.

Sobandi, Baban. 2003. Strategi Optimalisasi Pendapatan Asli Daerah (PAD): Kasus Kota Banjarmasin. Hasil Kajian Tentang "Pemberdayaan dan Penggalian Sumber-sumberPendapatan Asli Daerah". Pusat Kajian dan Pendidikan dan Pelatihan Aparatur I LAN. Bandung Tahun 2003.

Widjaja, HAW. 2002. Otonomi daerah dan Daerah Otonom. Jakarta: RajaGrafindo Persada.

\begin{tabular}{|c|c|c|}
\hline \multicolumn{3}{|l|}{$\begin{array}{l}\text { Undang-Undang } \\
\text { Daerah: }\end{array}$} \\
\hline \multicolumn{3}{|l|}{ Undang-Undang } \\
\hline Nomor 23 & Tahun & \\
\hline \multicolumn{3}{|c|}{ Pemerintahan Daerah. } \\
\hline \multirow{3}{*}{\multicolumn{3}{|c|}{$\begin{array}{l}\text { Undang-Undang Republik Indonesia } \\
\text { Nomor } 28 \text { Tahun } 2009 \text { Tentang Pajak } \\
\text { Daerah dan Retribusi Daerah. }\end{array}$}} \\
\hline & & \\
\hline & & \\
\hline Undang-Undang & Republik & Indones \\
\hline Nomor 32 & Tahun & \\
\hline \multicolumn{3}{|c|}{ Pemerintahan Daerah. } \\
\hline Undang-Undang & Republik & Indones \\
\hline Nomor 33 & ahun & \\
\hline $\operatorname{tgan} \mathrm{D}$ & & \\
\hline
\end{tabular}

